Yuliani Winarti ${ }^{1}$, Rini Ernawati ${ }^{1}$

${ }^{1}$ Universitas Muhammadiyah Kalimantan Timur

Corresponding Author: Yuliani Winarti

Email: yulianiwinarti@gmail.com

\section{Effectiveness of Peer Education Method in Increasing Knowledge and Attitude Towards HIV/AIDS Prevention among Students in Samarinda}

\begin{tabular}{ll}
\hline Article Info & \\
Online & $:$ http://journal.umy.ac.id/index.php/ijnp \\
ISSN & $: 2548$ 4249 (Print) \\
& $: 2548$ 592X (Online) \\
DOI & $: 10.18196 /$ ijnp.32100
\end{tabular}

Background: The rise of HIV/AIDS cases on teenagers aged 15 to 24 years old has reached 25\%. Inadequate knowledge regarding HIV/AIDS has been particular issue contributing to the rise of the cases.

Objective: This study aims to find out the effectiveness of peer education methods on knowledge and attitudes regarding HIV/AIDS prevention in students of SMK Kesehatan in Samarinda.

Method: This study is a quasi-experimental design with a nonequivalent control group of pre-test and post-test. The sample of the study was 60 students of SMK Kesehatan in Samarinda, selected through purposive sampling, and it was divided into an experimental group that was exposed to the treatment of the peer education method, also, the other 30 students in the control group were only given a module. Data analysis used paired t-test with a significant level of $p=0.05$

Result: The result found significant differences before and after intervention in intervention groups between pre and post-test of knowledge $(t=-3.83, p=0.01)$ and attitudes $(t=-4.54, p=0.00)$. A significant increase in knowledge and attitudes in the treatment group was higher than the control group.

Conclusion: The peer education method is effective to increase the knowledge and positive attitudes of the students of SMK Kesehatan in Samarinda.

Keywords: health education; peer education; prevention of HIV/AIDS

\section{INTRODUCTION}

The spread of HIV/AIDS has increased rapidly, and it is proven by the data of the World Health Organization (2016) showing that there is a rise in the number of people living with HIV/AIDS (PLWHA) from the group of age less than 15 years old. Fewer people died of HIV-related causes, with an estimated 1.1 million (range of 940,000-1.3 million) deaths in 2015; $43 \%$ from 2003 , the date that treatment targets were first set. In 2015, new HIV infection was estimated at 2.1 million (range of 1.8-2.4 million). More than 2 million teenagers aged between 10 and 19 years old live with HIV/AIDS. The most dominant factors of this spread is the transmission through sexual intercourse, injected drugs, prenatal, and homosexual (Kemenkes Rl, 2013). The phenomenon of pre-marital sex has appeared amongst teenagers aged 10 to 24 years old, whether males and females (Oktriyanto and Alfiasari, 2019). The data from a Forum of Family Planning (PKBI) Samarinda revealed that $25 \%$ of teenagers aged $15-18$ years old have conducted pre-marital sex. 


\section{NURSTING \\ PRACTICES}

Research on basic health (2010) stated that most people aged 15-24 years old possess inadequate knowledge of maternity risks, fertility periods, and prevention of HIV/AIDS. The great efforts on socializing the danger of HIV/AIDS are not proven to be sufficient to raise the teenagers' knowledge about this disease. Half of the citizens $(57,5 \%)$ have heard about HIV/AIDS. Nonetheless, this percentage does not guarantee that they know about HIV/AIDS comprehensively since there are only $11,4 \%$ who have comprehended the knowledge about the disease. An intensive and comprehensive effort on prevention, protection, and rehabilitation is necessary to be carried out. One of the initiatives that can be done is health education through the peer education method (Adyani, Muflih, and Syafitri, 2019).

Get involved in social life is very important among the young people since in this pattern of intercommunication with their peer's teenagers development is influenced by their peers' behaviours to gain confidence (Liu, Zhao, Chen, Falk, and Albarracín, 2017). The protection, prevention, and treatment of HIV/AIDS in this group intensively and comprehensively need to be done, and one of the efforts in the form of health education is through a peer education program. Peer education is a strategy in which a person who has been trained from a group of targets that have a purpose as a link or networking system for their peers to effectively be able to encourage, support, and promote peer group in their healthy living.

\section{METHOD}

The design of this research is a quasi-experimental study with the non-equivalent control group containing pre-test and post-test design. This study was carried out with two students group of SMK Kesehatan in Samarinda. One group was given the education of HIV/AIDS through the peer education method, while the control group was assigned a module about the danger of HIV/AIDS to be read independently. This design was employed to see the effectiveness of the peer education method on the students' knowledge and attitudes towards the prevention of the HIV/AIDS spread. The sample of the study was 60 students of SMK Kesehatan in Samarinda selected using purposive sampling. The sample was divided into the experimental group that was given the treatment of the peer education method and the control group that was only given a module. The first group was the first-year students of SMK Kesehatan in Samarinda as the experimental group (30 students). The second group was the firstyear students of SMK Medika Samarinda as the control group (30 students). The criteria of the subjects are: (1) male / female from the first year (2) unmarried (3) range of age between 16 and 18 years old (4) non-member of PIK (Center of Counseling and Information) from BKKBN Samarinda (5) willing to participate in research.

The dependent variables are students' knowledge and attitudes towards the prevention of the HIV/AIDS spread. The independent variable is the health education method or information communication and education using the peer education method regarding the prevention of HIV/AIDS. The instrument of the research is a questionnaire with close-ended questions to measure students' knowledge and attitudes. The data were analysed using paired t-test to find the different mean scores of pre-test, post-test one, and post-test two for all variables after the treatment for both control and experimental group. The decision of hypothesis testing is taken with a significant level of $5 \%$ or $p$ value $=0.05$.

\section{RESULTS}

The respondents in this research who are qualified for the criteria of inclusion in each group were 30 people. Table 1 shows that most of the students in both groups were teenagers aged 15-17 years old, with a total number of 21 students $(70 \%)$ in the experimental group and 19 students $(63.3 \%)$ in the control group. Females dominated both groups in terms of the number of students. Meanwhile, in terms of origin, both groups showed various places, although students from Samarinda dominated with total of 18 students $(60 \%)$ in the experimental group and 23 students $(76.7 \%)$ in the control group. Since most of the respondents were from Samarinda, in the category of place of living, most students lived with their parents, 17 students $(56,7 \%)$ in the experimental group and 23 students (76.7\%) in the control group. 
Table 1. The characteristics of the respondents based on age, sex, origin, and place of living

\begin{tabular}{lcccc}
\hline & \multicolumn{5}{c}{ Group } \\
\cline { 2 - 5 } Characteristics & \multicolumn{3}{c}{ Intervention } & \multicolumn{3}{c}{ Control } \\
\cline { 2 - 5 } & $\mathrm{n}=30$ & $\%$ & $\mathrm{n}=30$ & $\%$ \\
\hline Age & & & & \\
15 years old & 8 & 26.7 & 7 & 23.3 \\
16 years old & 21 & 70.0 & 19 & 63.3 \\
17 years old & 1 & 3.3 & 4 & 13.4 \\
\hline Sex & & & & \\
Male & 6 & 20.0 & 7 & 23.3 \\
Female & 24 & 80.0 & 23 & 76.7 \\
\hline Origin & & & & \\
Samarinda & 18 & 60.0 & 23 & 76.7 \\
Kembang Janggut & 4 & 13.3 & 1 & 3.3 \\
Tenggarong & 2 & 6.7 & 1 & 3.3 \\
Kutai Timur & 2 & 6.7 & 1 & 3.3 \\
Sanga-Sanga & 2 & 6.7 & 0 & 0 \\
Kota Bangun & 1 & 3.3 & 0 & 0 \\
Kutai Barat & 1 & 3.3 & 4 & 13.3 \\
\hline Place of living & & & & \\
Rent House & 6 & 20.0 & 1 & 3.3 \\
With parents & 17 & 56.7 & 23 & 76.7 \\
With Family & 5 & 16.7 & 3 & 10.0 \\
Boarding house & 2 & 6.7 & 3 & 10.0 \\
\hline
\end{tabular}

The paired t-test analysis of students' knowledge between the intervention and control group is shown in Table 2.

Table 2. Analysis of paired t-test on students' knowledge of HIV/AIDS prevention (pre-test and posttest)

\begin{tabular}{|c|c|c|c|c|c|}
\hline \multicolumn{2}{|c|}{ Knowledge } & $\begin{array}{c}\text { Mean } \\
\text { (SD) }\end{array}$ & $\begin{array}{c}\text { Mean } \\
\text { Differences } \\
\text { (Cl 95\%) }\end{array}$ & $t$ & $p$ \\
\hline \multirow{2}{*}{ 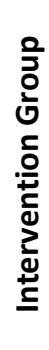 } & $\begin{array}{l}\text { Posttest } 1 \\
\text { with } \\
\text { pre-test }\end{array}$ & $\begin{array}{c}26.17 \\
(3.4) \\
23.47 \\
(2.2)\end{array}$ & $\begin{array}{c}-2.70 \\
(-4.13--1.26)\end{array}$ & -3.83 & $0.01 *$ \\
\hline & $\begin{array}{l}\text { Posttest } 2 \\
\text { with } \\
\text { Pretest }\end{array}$ & $\begin{array}{c}27.00 \\
(3.7) \\
23.47 \\
(2.2)\end{array}$ & $\begin{array}{c}-3.53 \\
(-5.13--1.93)\end{array}$ & -4.52 & $0.00 *$ \\
\hline \multirow{2}{*}{ 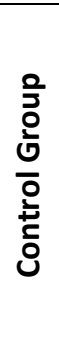 } & $\begin{array}{l}\text { Posttest } 1 \\
\text { with } \\
\text { pre-test }\end{array}$ & $\begin{array}{c}24.93 \\
(2.7) \\
25.43 \\
(4.0)\end{array}$ & $\begin{array}{c}0.50 \\
(-1.29-2.29)\end{array}$ & 0.56 & 0.57 \\
\hline & $\begin{array}{l}\text { Posttest 2 } \\
\text { with } \\
\text { Pretest }\end{array}$ & $\begin{array}{c}24.77 \\
(2.6) \\
25.43 \\
(4.0)\end{array}$ & $\begin{array}{c}0.66 \\
(-1.08-2.41)\end{array}$ & 0.77 & 0.44 \\
\hline
\end{tabular}

${ }^{*} \mathrm{P}=$ statististical significant $\alpha \leq 0.5$
The data on table 2 showed that there was a significant difference between before and after the treatment of the peer education method $(t=7.33$; $p<0.05)$ to the experimental group. The data on the post-test (Mean=26.17; $D=3.4$ ) were higher than the pre-test (Mean=23.47; $D=2,2$ ). It means that the treatment of peer education is effective in increasing the students' knowledge of the danger of HIV/AIDS in intervention group. Meanwhile, in the control group, in which students are only provided with a module of HIV/AIDS for self-reading, the statistical value did not show a significant difference between before and after the treatment $(t=0.16 ; p 0.57>0.05)$.

To analyse the difference between the two groups before and after the treatment. An analysis was conducted to measure the pre-test and post-test using paired t-test analysis. The results are presented in Table 3.

Table 3. Analysis of paired t-test on students' attitudes towards HIV/AIDS prevention (pre-test and posttest)

\begin{tabular}{|c|c|c|c|c|c|}
\hline \multicolumn{2}{|c|}{ Attitudes } & $\begin{array}{l}\text { Mean } \\
\text { (SD) }\end{array}$ & $\begin{array}{c}\text { Mean } \\
\text { Differences } \\
\text { (Cl 95\%) }\end{array}$ & $t$ & $p$ \\
\hline \multirow{2}{*}{ 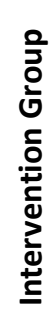 } & $\begin{array}{l}\text { Posttest } 1 \\
\text { with } \\
\text { pre-test }\end{array}$ & $\begin{array}{c}82.47 \\
(5.7) \\
76.80 \\
(4.4)\end{array}$ & $\begin{array}{c}-5.6 \\
(-8.21--3.11)\end{array}$ & -4.54 & $0.00 *$ \\
\hline & $\begin{array}{l}\text { Posttest } 2 \\
\text { with } \\
\text { Pretest }\end{array}$ & $\begin{array}{r}84.23 \\
(6.1) \\
76.80 \\
(4.4)\end{array}$ & $\begin{array}{c}-7.4 \\
(-10.2--4.61)\end{array}$ & -5.40 & $0.00 *$ \\
\hline \multirow{2}{*}{ 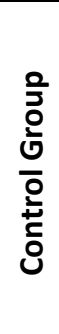 } & $\begin{array}{l}\text { Posttest } 1 \\
\text { with } \\
\text { pre-test }\end{array}$ & $\begin{array}{r}73.53 \\
(4.6) \\
73.77 \\
(4.9)\end{array}$ & $\begin{array}{c}0.23 \\
(-0.05-0.52)\end{array}$ & 1.6 & 0.10 \\
\hline & $\begin{array}{l}\text { Posttest } 2 \\
\text { with } \\
\text { Pretest }\end{array}$ & $\begin{array}{r}73.57 \\
(4.3) \\
73.77 \\
(4.9)\end{array}$ & $\begin{array}{c}0.20 \\
(-0.39 .-0.79)\end{array}$ & 0.6 & 0.49 \\
\hline
\end{tabular}

Based on table 3 , the intervention group that was exposed to treatment through peer education method demonstrated a significant difference between before and after the treatment, in both phases of pretest-posttest 1 and pretest-posttest 2 ( $p$-value< 0.05).

The mean score of posttest 1 (Mean $=82.47 ; 5.7$ ) on the student's attitudes was higher than the pre-test 


\section{NURRSING \\ PRACTICES}

score (Mean $=76.8 ; 4.4$ ), and there was a difference of -5.6 between the pre-test and the posttest 1 . The mean score of posttest 2 (Mean $=84.23 ; 6.1$ ) on the student's attitudes was higher than the pre-test score (Mean= $76.8 ; 4.4$ ), and there was a difference of -7.4 between the pre-test and the posttest 2 . These statistical numbers show the empirical evidence of health education through the peer education method is effective in improving the students' attitudes towards the prevention of HIV/AIDS.

On the other hand, the data show that the students in the control group did not improve their attitudes towards the prevention of HIV/AIDS ( $p$-value>0.05 in both pretest and posttest). The mean score of the posttest $1(73.53 ; 4.6)$ was lower than the mean score of the pre-test $(M=76.8 ; 4.4)$. Similarly, the mean score of posttest 2 was smaller than the pre-test. All things considered, providing a module of HIV/AIDS prevention for self-reading is not effective in improving the students' attitude in the control group.

\section{DISCUSSION}

Based on the result of this research in Table 2 and Table 3, there was a significant increase in the students' knowledge and attitudes towards the prevention of HIV/AIDS from the experimental group. This increase is a result of health education that is given by a peer educator. With the peer education method, the teenagers are given the opportunity to develop their communication and interaction skills among themselves, especially matters that are related to the prevention of HIV/AIDS. According to Jennings and Protte (2014), this program can increase the students' knowledge and attitudes towards the prevention of youths' risky behaviours, including the spread of HIV/AIDS.

Health education through peer education is proven to be effective in helping young people to prevent HIVrisk behaviours. Many ways can be done to conduct health education, such as socialization at schools and certain institutions, displaying banners and posters, etc. However, from many methods that can be done, the peer-based education method is so far one of the most effective ways (Ningrum and Sumaryani, 2018). Furthemore, the methods that are used by peer educators in delivering information are different from other conventional techniques. They had the freedom to express many things and able to discuss it. Moreover, they could provide information about the danger and the prevention of HIV/AIDS in a more informal way. Also, peer educators have known their friends very well. It gives them the advantage so that their friends will not hesitate to ask questions. A friendly atmosphere is also created during the process of delivering information since they know each other, and they are a group with small numbers. Therefore, the delivery of information is conducted more effectively and more focused. A teenager may become an active agent in transferring knowledge about reproduction health and HIV/AIDS prevention. Besides, they may become an alternative for the other teenagers to get the information so that they can develop their skills and knowledge to prevent HIV/AIDS (Feith, Gradvohl, Füzi, Darvay, Krekó, and Falus, 2018).

The availability of the time that does not disturb the students/teenagers is also a factor that helps the students from the experimental group to develop their knowledge (Fertman, and Allensworth, 2016). The success of health education is determined by the strategies, methods and tools used to support the process of learning. Some factors of the disastrous results from the control groups are lack of repetition from the source of the information and one-way communication, which makes it more difficult for the students to remember the information since they might store it in short-term memory.

The increase of the knowledge from the experimental group is supported by choosing well-trained peers. Criteria of peer educators who are recruited are according to his/her popularity among his/her friends and whether or not they fond of him/her (Sun, Miu, Wong, Tucker, and Wong, 2018). A positive role model may enhance their self-confidence in developing their ability to deliver information so that a change can occur (Mason-Jones, 2011).

Based on the results of the statistical analysis in Table 2 and Table 3, the peer education method is empirically proven as an effective method to educate students of vocational high schools about HIV/AIDS from the experimental group. Selecting a good peer educator and his/her characteristics are also very crucial since the peer educator has a vital role in helping attitude changes. According to Ningrum and Sumaryani (2018), the success of the educator to 
increase the students' attitudes relies on the recruitment process and the training process. The meeting frequency, relaxed delivery, and informal communicative delivery between the peer educators and the other students have supported the raise of positive attitudes. Besides, peer educators and peer groups usually have known each other long before the treatment. This condition gives the advantage to the peer educator to create a friendly atmosphere so that the peer group might ask the question and discuss related topics without hesitation. In line with Sarwono, S (2011) states that one may change by gaining information from the others through persuasion or social pressure. Effective communication used by peer educators to an experimental group supports the increase of students' positive attitudes towards the prevention of the spread of HIV/AIDS (Jenings and Protte, 2014).

Peer educators may hold essential roles to improve the quality of delivery within the frame of health promotion, including the prevention of HIV/AIDS. According to Maio, Haddock, and Verplanken (2018) stimulation is necessary before a change in someone's attitude has been made. This change cannot be reached unless there are supporting infrastructures and facilities to create health awareness. The information transfer conducted by a peer educator has become a guide for the peer groups to act, and the results show that the students from the experimental group had done better attitudes in HIV/AIDS prevention than ever before.

Health belief model (HBM) theory described that healthy lifestyle is determined by whether or not people: (1) see themselves at risk of health problems (2) see the problem as a serious matter (3) ensure that they will recover and get benefit from their effort of medication (4) recognize their needs to take action and the circumstances that may make their action slow. The education of health through peer educators can create a good impression for the peer groups since the information delivery process is usually not intimidating. Therefore, they will be able to gain a better understanding regarding the danger of HIV/AIDS and its prevention as early as possible. The problems that are encountered by the subjects of the research can be diagnosed early when the peer educator is employed. It is due to the members of the peer group has more freedom to express themselves because the educator is their friend. Hence, the subjects of the research from the experimental group have better knowledge and attitudes about HIV/AIDS prevention through peer educators (Fertman, and Allensworth, 2016).

Based on the analysis, non-significant change attitudes in the control group exist because the subjects do not have the opportunity to have a twoway communication since they read the module by themselves. They need to be highly committed to obtain more information from the module and reread the book. Therefore, they are cannot develop their knowledge and attitudes about preventing HIV/AIDS as expected. Also, the control group has a decreased score in the posttest compared with the score from the pre-test. It is due to less repetition done by the students in the process of reading the module so that the information they read usually be stored in the short-term memory (Astari, \& Fitriyani, 2019). As a result, the students do not have an excellent comprehensive understanding about the prevention of HIV/AIDS. It is in line with the statement from Kasih (2016) that the success of health education is also determined by the appropriate strategy, method, and tools which can support the success of the process of learning. Ibrahim et al. (2012) stated that the improvement of students' knowledge and attitudes towards the prevention of HIV/AIDS can be developed through the continuous delivery of information.

\section{CONCLUSION}

It can be concluded that the peer education method is effective in increasing the knowledge and positive attitudes of the students of SMK Kesehatan in Samarinda.

\section{REFERENCES}

Adyani, S. A. M., Muflih, M., \& Syafitri, E. N. (2019). Kerentanan Kehamilan Remaja Dan Konseling Sebaya: Tinjauan Teori. Jurnal Keperawatan Respati Yogyakarta, 6(1), 552557.

Astari, R., \& Fitriyani, E. (2019). Pengaruh Peer Education terhadap Pengetahuan dan Sikap Remaja Tentang Pencegahan Hiv-aids di Smk Korpri Majalengka. Jurnal IImu Kesehatan Bhakti Husada: Health Sciences Journal, 10(2), 143-152.

Depkes, R. I. (2013). Riset kesehatan dasar. Jakarta: Badan Penelitian dan pengembangan Kesehatan Kementrian Kesehatan RI. 


\section{NURERINING \\ PRACTICES}

Feith, H. J., Gradvohl, E., Füzi, R., Darvay, S. M., Krekó, I. B., \& Falus, A. (2018). Health EducationResponsibility-Changing Attitude. A New Pedagogical and Methodological Concept of Peer Education. Acta Universitatis Sapientiae, Social Analysis, 8(1), 55-74.

Fertman, C. I., \& Allensworth, D. D. (2016). Health promotion programs: from theory to practice. John Wiley \& Sons

Ibrahim, N., Rampal, L., Jamil, Z., \& Zain, A. M. (2012). Effectiveness of peer-led education on knowledge, attitude and risk behavior practices related to HIV among students at a Malaysian public university-a randomized controlled trial. Preventive medicine, 55(5), 505-510.

Jennings, J. M., Howard, S., \& Perotte, C. L. (2014). Effects of a school-based sexuality education program on peer educators: the Teen PEP model. Health Education Research, 29(2), 319-329.

Kasih, L. C. (2016). Efektifitas Peer Education Pada Pengetahuan Dan Sikap Siswa SMA Dalam Pencegahan HIV/AIDS. Jurnal IImu Keperawatan, 4(2), 26-33.

Kemenkes, R. I. (2013). Laporan Triwulan Situasi Perkembangan HIV/AIDS di Indonesia.

Liu, J., Zhao, S., Chen, X., Falk, E., \& Albarracín, D. (2017). The influence of peer behavior as a function of social and cultural closeness: A meta-analysis of normative influence on adolescent smoking initiation and continuation. Psychological bulletin, 143(10), 1082.

Maio, G. R., Haddock, G., \& Verplanken, B. (2018). The psychology of attitudes and attitude change. Sage Publications Limited.

Mason-Jones, A. J., Flisher, A. J., \& Mathews, C. (2011). Who are the peer educators? HIV prevention in South African schools. Health education research, 26(3), 563-571.

Ningrum, S. A. W., \& Sumaryani, S. (2018). Peer Education Prevents Sexual Risk Behavior Among Adolescents in Rural Area. Indonesian Nursing Journal of Education and Clinic (INJEC), 2(2), 193-199.

Oktriyanto, O., \& Alfiasari, A. (2019). Dating and Premarital Sexual Inisiation on Adolescence in Indonesia. KEMAS: Jurnal Kesehatan Masyarakat, 15(1), 98-108.

Sarwono, S. W. (2011). Psikologi Remaja edisi revisi. Jakarta: Rajawali Pers.

Sun, W. H., Miu, H. Y. H., Wong, C. K. H., Tucker, J. D., \& Wong, W. C. W. (2018). Assessing participation and effectiveness of the peerled approach in youth sexual health education: systematic review and metaanalysis in more developed countries. The Journal of Sex Research, 55(1), 31-44.

World Health Organization. (2014). The global health sector strategy on HIV. 